\title{
Effects of Emotional and Spiritual Intelligence on Job Performance among Temporary Nurses at Abdul Riva'i Regional General Hospital, Berau District, East Kalimantan Province, Indonesia
}

\author{
Siswoyo Haryono ${ }^{1 *}$, Febry Rosady ${ }^{2}$, Mohd Shamsuri MdSaad ${ }^{3}$ \\ ${ }^{1}$ Universitas Muhammadiyah Yogyakarta.Bantul, Yogyakarta 55183, Indonesia \\ ${ }^{2}$ Master of Management, Uniersitas Muhammadiyah Yogyakart, Bantul, Yogyakarta 55183. Indonesia \\ ${ }^{3}$ Centre for Technopreneur Development \& Department of Human Development
}

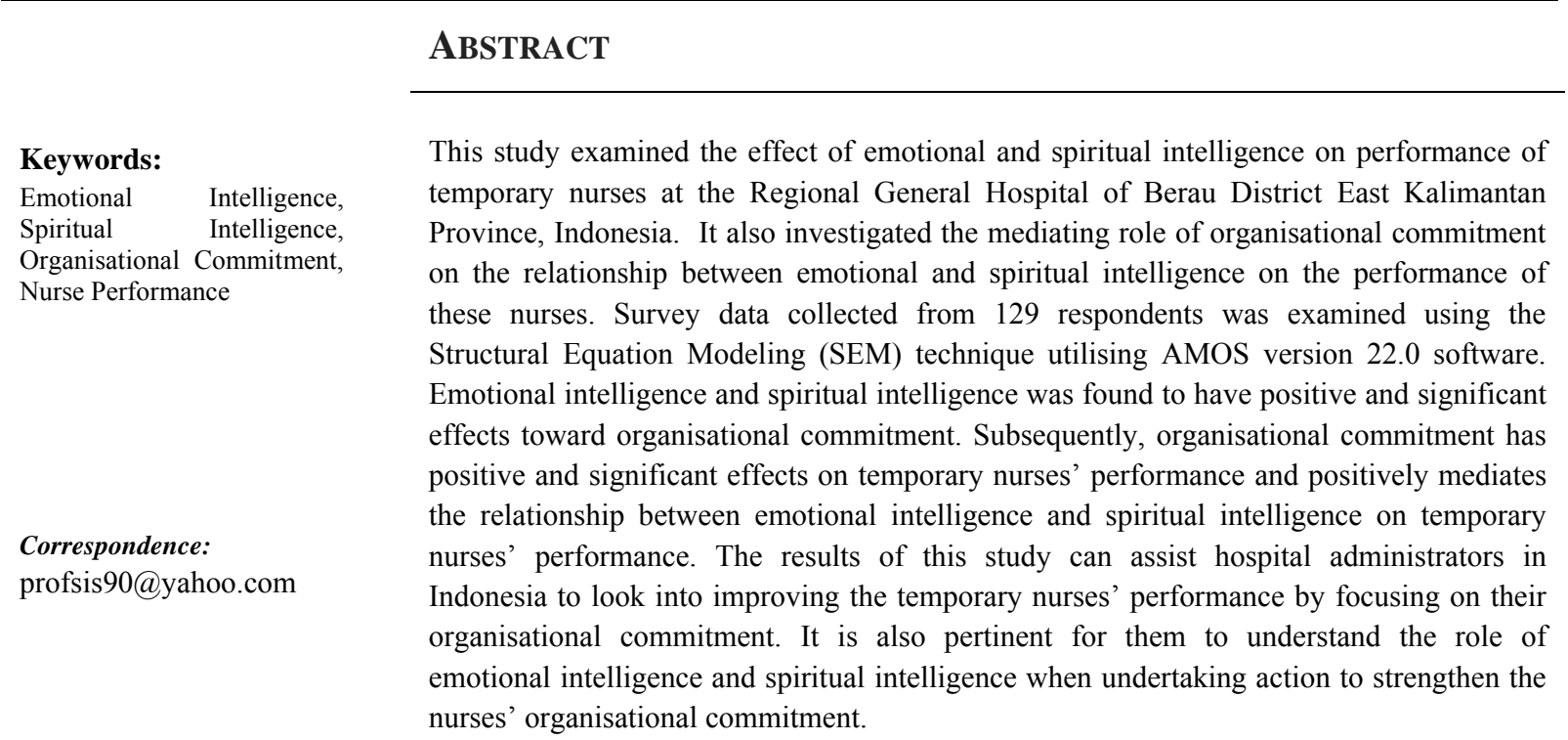


Highly skilled and competent health workforce is needed in public health service. It has a very important role in fulfilling the needs of public health services. In fact, there are still many health workers, especially nurses who have low performance. It causes the emergence of negative perceptions concerning the health workers' performance. This problem is expected to be addressed appropriately.

Poor nurse performance can be indicated by the lack of a sense of responsibility, sincerity, self-awareness and professionalism in serving the community. These aspects are related to the level of emotional and spiritual intelligence of the nurses. Emotional and spiritual intelligence has very important role in supporting the performance of nurses. When a person has a high emotional intelligence, he will be able to solve the problems encountered. Similarly, when a person has a high spiritual intelligence, the person will have a sense of self and good sincerity in their hearts. When two aspects of intelligence are possessed by a nurse, it will encourage performance and increase commitment toward tasks at workplace. In reverse, there is a relation between spiritual intelligence and occupational stress of employees (Ahmadian, Hakimzadeh, \& Kordestani, 2013).

This statement is in line with the study of Ma, Xing, Wang, and Chen (2013) that showed high performing employees is not only actively solving problems but also enjoy working with other colleagues. This means that if an individual's emotional intelligence is good then the performance in the organisation environment will also be good. In addition, emotional intelligence also has a positive influence on organisational commitment (Alavi Mojtahedzadeh, Amin, \& Savoji, 2013). Similarly, Entesar Foumany and Danshdost (2014) mentioned that the aspect of religion positively affects organisational commitment in nurses which indirectly indicating productivity.

Apart from the aspects of intelligence, organisational commitment becomes the determinant factor of nurse performance level. According to Robbins (1996), organisational commitment is an attitude that reflects feelings of likes or dislikes of the organisation where an employee works. When a person has a high organisational commitment then the individual will be loyal in the sense of making various efforts towards the success of the organisation. This will have an impact on the productivity of the nurses. This statement is in line with Khan, Ziauddin, and Ramay's (2010) research which revealed a positive relationship between organisational commitment and employees' job performance. In the comparative analysis of three dimensions of organisational commitment, normative commitment has a positive and significant impact on employees' job performance. The purpose of this research is to empirically study the temporary nurses' perceptions on the effects of emotional and spiritual intelligence on job performance among the temporary nurses in Abdul Riva'i Regional General Hospital, Berau district, East Kalimantan Province, Indonesia.

\section{Hypothesis Development}

\section{The Relationship between Emotional Intelligence and Organisational Commitment}

The results of the research by Shafiq and Rana (2016) revealed a significant influence of emotional intelligence on organisational commitment. Emotional intelligence also showed a significant positive relationship with the three components of organisational commitment including affective, continuity and normative commitment. Emotional intelligence reflects a reasonable predictive power of teachers' organisational commitment. The study suggested that 
emotional intelligence should be included in teacher selection and recruitment criteria, and used as an intervention to increase teacher organisational commitment to Pakistani colleges. Research conducted by Mohamadkhani and Lalardi (2012) indicated that emotional intelligence can create the desired relationship within the organisation because every organisation is generally customer-oriented, i.e. client and staff. High organisational commitment can be regarded as a key factor in their existence. Staff with high emotional intelligence can hold a higher organisational commitment to their organisation. The findings of this study indicated the need to employ individuals with high emotional intelligence.

In their studies, Rathi and Rastoghi (2009), Alavi et al. (2013), and Rozeman (2007) found that there is a significant relationship between organisational commitment and emotional intelligence. Skill is the most important dimension of emotional intelligence. Emotional intelligence gives the ability to enjoy the true feelings and makes the right decision in difficult conditions. Goleman (2006) sets emotional intelligence as an intelligence that refers to the ability to recognize our own feelings and the feelings of others, self-motivating ability and the ability to manage emotions well on oneself and in relation to others. Based on the above elaborations, the hypothesis can be drawn as follows:

$\mathbf{H}_{\mathbf{1}}$ : Emotional intelligence positively affects organisational commitment

\section{The Relationship between Spiritual Intelligence and Organisational Commitment}

Research by Kalantarkousheh, Sharghi, Soleimani, and Ramezani (2014) shows the differences in the amount of spiritual intelligence and organisational commitment between men and women, both higher in men. There is a definite correlation between spiritual intelligence and organisational commitment among staff. Higher spiritual intelligence is associated with higher organisational commitment, which is evident both for men and women. Zohar and Marshall (2001) interpret spiritual intelligence as an intelligence to deal with the problem of meaning or value, the intelligence to put our behavior and life in the context of a wider and richer meaning, the intelligence to judge that one's actions or ways of life are more meaningful than others. In addition, Zohar and Marshall (2000) also revealed that a person with high spiritual intelligence tends to be a dedicated leader and is responsible for bringing in a higher vision, value and can inspire others.

Another research conducted by Awais, Malik, and Qaisar (2015), EntesarFoumany and Danshdost (2014), and Kalantarkousheh, et al. (2014) showed a positive and significant correlation between spiritual intelligence and organisational commitment. Meyer and Allen (1984) suggested three components of organisational commitment: 1) Affective Commitment, occurs when employees want to be part of the organisation because of the emotional attachment or feel the same value with the organisation, 2) Continuance Commitment, the individual's willingness to remain in the organisation for not finding any other job or due to certain economic rewards, 3) Normative Commitment, arising from the values of the employees. Employees survive as members of the organisation because there is awareness that being committed to the organisation is the right thing to do. Based on the above elaborations, the hypothesis can be drawn as follows:

$\mathbf{H}_{2}$ : Spiritual intelligence positively affects organisational commitment. 


\section{The Relationship between Emotional Intelligence and Job Performance}

The results of research conducted by Akhtar, Ghufran, Husnain, and Shahid (2017) showed that emotional intelligence has a positive impact on employees' performance and perceived organizational support moderates the relationship between emotional intelligence and work performance so that the relationship between emotional intelligence and work performance is stronger or positive. According to Ma et al. (2013), high performance employees not only actively solve problems but also enjoy working with other employees. When someone has a good emotional intelligence then the performance of a person in the environment of the organisation is also good. The study findings by Vratskikh, Al-Lozi, and Maqableh (2016) confirmed the role of mediator job satisfaction in the relationship between emotional intelligence and performance. It is suggested that emotional intelligence can be used to predict performance and job satisfaction, therefore understanding the theory of emotional intelligence can be promoted for managerial and human resource practices across public sector organisations.

Shih and Susanto (2010) also found that emotional intelligence is the antecedent of conflict management within a company. In addition, it also illustrates the immediate effects of conflict management on performance. The study also confirms that conflict management mediates the relationship between emotional intelligence and performance. The results of this study indicate that emotional intelligence in public organisations has an impact on performance similar to that of emotional intelligence in private organisations. Based on the above elaborations, the hypothesis can be drawn as follows:

$\mathbf{H}_{3}$ : Emotional intelligence positively affects job performance.

\section{The Relationship between Spiritual Intelligence and Job Performance}

Utomo, Nimran, Hamid, and Utami (2014) noted that there is a significant and positive relationship between spiritual intelligence and job performance. Zohar \& Marshall (2001) stated that when spiritual intelligence is high, people seem to have the right intellectual and behavior. However, when spiritual intelligence is low, people seem to have problematic behavior. They claimed that people with high spiritual intelligence demonstrate a measure of satisfaction and high performance. Subsequent research by Rani, Abidin, and Hamid (2013) demonstrated that work performance is influenced by spiritual intelligence. Also, the moderating factor of age and tenure is not significant that the model is applicable to all hospitals involved. This finding may pave the way forward for empowering spiritual intelligence in nursing school and training to enhance nurse's work performance.

The same research results that were conducted by Jasour and Avarsin (2016), Hasannudin and Sjahruddin (2017), Asghari and Shirvani (2015), Estanesti (2016) and Mahmood, Arshad, Ahmed, Akhtar, and Rafique (2015) also revealed the same findings that confirmed meaningful relationship between spiritual intelligence and job performance which reflects the importance of paying attention to spiritual intelligence for managers in organisation. Based on the above elaborations, the hypothesis can be drawn as follows:

$\mathbf{H}_{4}$ : Spiritual intelligencepositively affectsjob performance 


\section{The Relationship between Organisational Commitment and Job Performance}

Research on the effect of organisational commitment toward job performance conducted by Khan et al. (2010) indicated a positive relationship between organisational commitment and employee performance. In a comparative analysis of three dimensions of organisational commitment, normative commitment has a positive and significant impact on worker performance. Furthermore, this study explores employee job performance with four demographic variables, resulting in high achieving male employees dealing with their female counterparts. Hafiz (2017) conducted a research to find out the relationship dimension of organisational commitment and employee performance in private banks and commercial banks of Lahore. The study found that the three elements of organisational commitment according to Meyer and Allen (1984) : affective commitment occurs when employees want to be part of the organisation because of emotional attachment or feel they have the same value as the organisation, normative commitment arising from the values of employees, and continual commitment is the willingness of individuals to remain in the organisation for not finding any other job or due to certain economic rewards are important factors in improving the performance of bank employees. The results showed that the dimensions of organisational commitment independently and together affect the performance of employees in the bank. This means that employees are willing to devote their energy and mind to complete their work, because they share the same goals and values within the organisation.

Research done by Tolentino (2013) revealed that academic personnel have stronger affective and normative commitment than the administrative while the administrative personnel has a stronger continuance commitment than the academic. Both the academic and administrative personnel are performing very well in their job. Among the academic, only affective commitment correlates significantly with job performance while among the administrative personnels, not a single commitment dimension is related to job performance. Research that was done by Al Zefeitiand Mohamad (2017) showed that their empirical results indicate that all organisational commitment subscales (affective, normative, and continuance) have a significant impact on work performance dimensions, contextual and task performance. Abarghuee, Broujerdi, Naderian, and Taherpour (2014) also conducted a research that revealed almost the same results. The results showed that there is a significant relationship between organisational commitment and job performance among sport teachers at high schools. However, analysis of the three components of organisational commitment separately indicated that among the components of affective commitment, continuance commitment and normative commitment, only affective commitment had a significant relationship with job performance.

$\mathbf{H}_{5}$ : Organisational commitment positively affectsjob performance

\section{Method}

\section{Research Design and Unit Analysis}

This research employs quantitative research method by developing reliable and valid research instrument on emotional intelligence, spiritual intelligence, organisational commitment and job performance perceived by temporary nurses. The unit analysis of this research is temporary nurses who work at Abdul Riva'i Regional General Hospital, Berau District, and East Kalimantan Province, Indonesia. 


\section{Scale Measurement}

All the variables in this research, i.e. emotional intelligence, spiritual intelligence, organisational commitment and job performance were measured with 1-5 Likert scale instrument. The scale represents the rating from 'strongly disagree' to 'strongly agree'.

\section{Research Sample}

Total respondents were selected purposely among130 temporary nurses who work at Abdul Riva'i Regional General Hospital, Berau District, and East Kalimantan Province, Indonesia. The data was gathered through face to face distribution by the researcher.

\section{Data Screening and Analysis}

Data screening test on the first stage of data processing in this research were carried out in two steps: data normality and data outlier checking. Based on the survey distributed, all 130 questionnaires were filled out completely. AMOS 22.0 version was used to analyse the data and answer the hypothesis. The design of this research is first order SEM (Structural Equation Modelling). Indicators that form variables were tested with goodness of fit (GOF) technique. The variables were developed as follows:

Employee performance is a measure that can be used to define the comparison of the results of execution of tasks, the responsibilities given by the organisation in a certain period and can be used relatively to measure employee or organisational performance (Gibson, Ivancevich, and Donelly (2011). This variable has five indicators that have been developed by Mathis and Jackson (2011): output quality, output quantity, output period, work attendance and cooperative attitude. Emotional intelligence is an intelligence that refers to the ability to recognise our own feelings and the feelings of others, the ability to motivate oneself, the ability to manage emotions well on oneself and in relation to others. This variable also has five indicators that have been developed by Goleman (2006): self-awareness, self-adjustment, motivation, empathy and social skills. Spiritual intelligence is an intelligence to deal with the question of meaning or value, the intelligence to put our behaviour and life in the context of broader and richer meaning, the intelligence to judge that one's actions or ways of life are more meaningful than others. This variable has four indicators that have been developed by Zohar and Marshall (2001) and Agustian (2003): integrity, wisdom, respect for life and courage. Organisational commitment is defined as one attitude that reflects feelings of pleasure and displeasure at the organisation at work (Robbins, 1996). There are three indicators related to organisational commitment described by Meyer and Allen (1984): affective, continuance and normative.

Measurement model would apply convergent validity to test those indicators whether or not they are valid. Maximum Likelihood Estimation (MLE technique was used in this research. Assessment of the questionnaire items was done by Confirmatory Factor Analysis (CFA) to test the construct relation with the indicator based on the developed theory. Cronbach's Alpha was also used to test the reliability of the constructs.

CFA test result shown on Table 1 indicates that the value for loading factor in each question item was $>.5$ which can conclude that all the question items are valid. Meanwhile, Table 2 showsthat the value of Construct Reliability is $\geq .7$ and Variance Extracted is $\geq .5$ for each construct, which explain that all constructs are reliable. The results of CFA test conclude that all indicators can be used to measure the variables and to analyse research data. 
Table 1

Validity Test Result Based on Fit Model

\begin{tabular}{|c|c|c|}
\hline Constructs and Indicators & Estimate $(\lambda \geq 0.5)$ & Result \\
\hline \multicolumn{3}{|l|}{ Job Performance (JP) : } \\
\hline JP1 (Output quality) & 0.755 & Valid \\
\hline JP2 (Output quantity) & 0.884 & Valid \\
\hline JP3 (Output period) & 0.843 & Valid \\
\hline JP4 (Work attendance) & 0.857 & Valid \\
\hline JP5 (Cooperative attitude) & 0.884 & Valid \\
\hline \multicolumn{3}{|c|}{ Emotional Intelligence (EMI): } \\
\hline EMI1 (Self-awareness) & 0.825 & Valid \\
\hline EMI2 (Self-adjustment) & 0.748 & Valid \\
\hline EMI3 (Self-motivation). & 0.778 & Valid \\
\hline EMI4 (Empathy) & 0.743 & Valid \\
\hline EMI5 (Social skills) & 0.775 & Valid \\
\hline \multicolumn{3}{|l|}{ Spiritual Intelligence (SPI): } \\
\hline SPI1 (Integrity) & 0.917 & Valid \\
\hline SPI2 (Wisdom) & 0.797 & Valid \\
\hline SPI3 (Respect for life) & 0.939 & Valid \\
\hline SPI4 (Courage) & 0.820 & Valid \\
\hline \multicolumn{3}{|c|}{ Organisational Commitment (OC): } \\
\hline OC1 (Affective) & 0.789 & Valid \\
\hline OC2 (Continuance) & 0.738 & Valid \\
\hline OC3 (Normative). & 0.864 & Valid \\
\hline
\end{tabular}

Table 2

Reliability Test Result Based on Fit Model

\begin{tabular}{lccc}
\hline Variables & Construct Reliability $\geq 0.7$ & Variance Extracted $\geq 0.5$ & Result \\
\hline Job Performance (JP) & 0.78 & 0.65 & Reliable \\
Emotional Intelligence (EMI) & 0.76 & 0.52 & Reliable \\
Spiritual Intelligence (SPI) & 0.79 & 0.66 & Reliable \\
Organisational Commitment (OC) & 0.93 & 0.84 & Reliable \\
\hline
\end{tabular}

\section{Results}

Hypothesis testing in this research was analysed by using first order Structural Equation Modelling (SEM) with AMOS 22.00. The full SEM test result can be seen in Figure 1. Meanwhile, Table 3 explains the assumption of test result in SEM development. Confirmatory test of full model exposes fit model which means compliance with goodness of fit criteria. Model structure was used to draw research causality models with structural relationship. The goodness of fit test result is as follows: Chi-Square $=324.22$, probability $=.05$, GFI $=.90$, 
$\mathrm{AGFI}=.93, \mathrm{TLI}=.94$ and $\mathrm{RMSEA}=.01$. All the value of Chi-Square, probability, TLI, GFI, AGFI, and RMSEA already meet the required cut-off value. It indicates that the research model is fit and meets the standard criteria to analyse and test the proposed hypothesis.

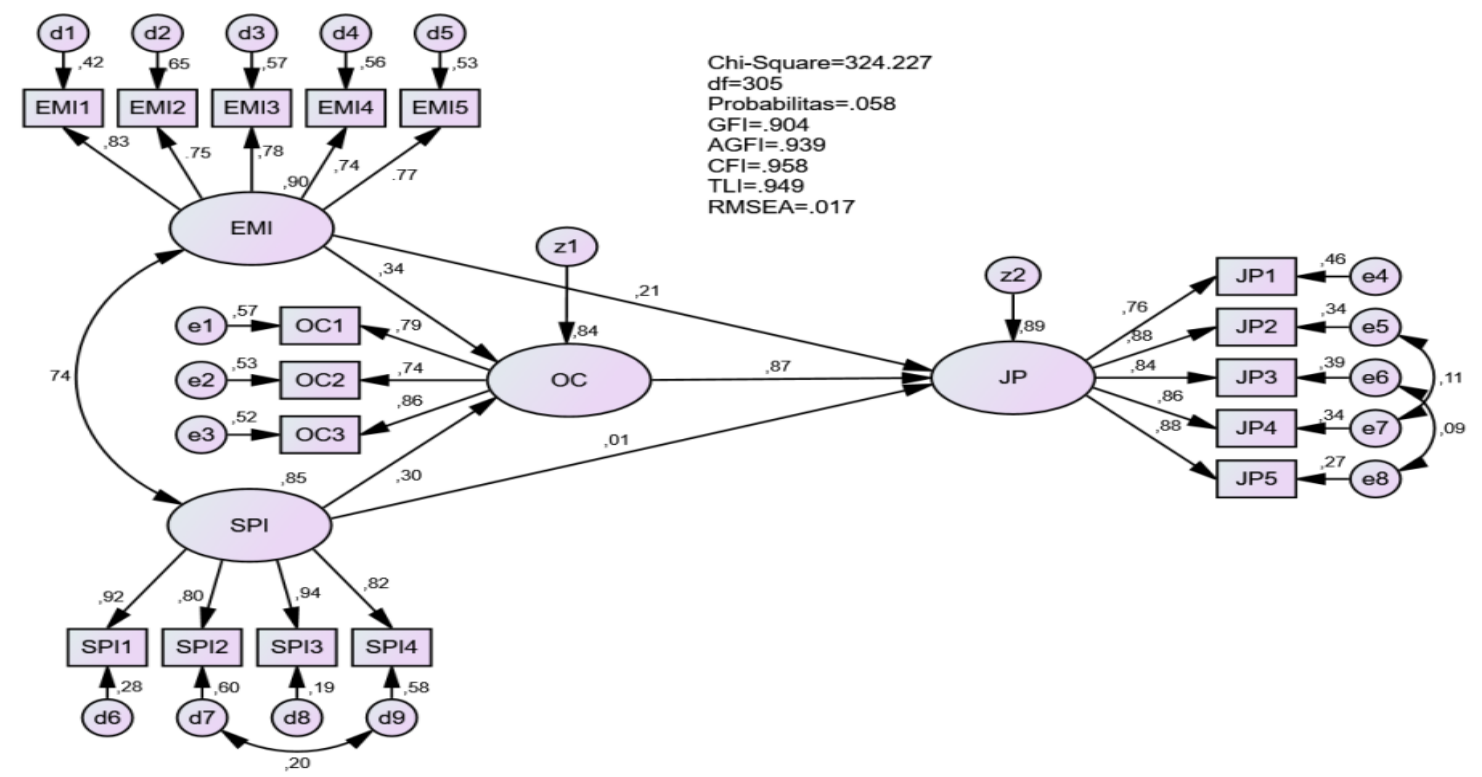

Figure 1. Effects of emotional and spiritual intelligence on job performance among temporary nurses at Abdul Riva'i Regional General Hospital, Berau District, East Kalimantan Province, Indonesia.

Table 3

Structural Parameter Estimates Direct Effect: Path Analysis Model $(N=130)$

\begin{tabular}{cccccc} 
Hypothesis & Structural Path & Path Coefficients & $t$ & $p$ & Results \\
\hline $\mathrm{H}_{1}$ & Emotional Intelligence $\rightarrow$ Org. Commitment & .34 & 2.71 & .007 & Significant \\
$\mathrm{H}_{2}$ & Spiritual Intelligence $\rightarrow$ Org. Commitment & .29 & 2.38 & .01 & Significant \\
$\mathrm{H}_{3}$ & Emotional Intelligence $\rightarrow$ Job. performance & .21 & 2.60 & .009 & Significant \\
$\mathrm{H}_{4}$ & Spiritual Intelligence $\rightarrow$ Job. Performance & .01 & .005 & .99 & Not-Significant \\
$\mathrm{H}_{5}$ & Org. Commitment $\rightarrow$ Job. Performance & .87 & 7.62 & $* * *$ & Significant \\
\hline
\end{tabular}

\section{Relationship between Emotional Intelligence and Organisational Commitment}

The results of hypothesis 1 testing explain that emotional intelligence significantly affects organizational commitment $(t=2.71>1.96)$ with significance value $(.007<.05)$. Thus, hypothesis 1 is accepted. The results indicate that there is a positive and significant relationship between emotional intelligence and organisational commitment. These results are consistent with research conducted by Rathi and Rastoghi (2009) and Rozeman (2007). In their study they found a significant relationship between emotional intelligence and organisational commitment. The findings are also supported by Shafiq and Rana (2016) which concluded that there is a significant relationship between emotional intelligence and the commitment of higher education organisations in Pakistan. The results of this study are also in line with research done by Alavi et al. (2013) which stated that emotional intelligence and job satisfaction are positively and significantly correlated to organisational commitment. There is also another 
research conducted by Mohamadkhani and Lalardi (2012) which concluded that emotional intelligence can create the desired relationship within the organisation, because every organisation is generally customer-oriented, i.e. client and staff. High organisational commitment can be regarded as a key factor in their existence. Staff with high emotional intelligence can hold a higher organisational commitment towards their organisation. The findings of this study indicated the need to employ individuals with high emotional intelligence.

The results of research by Shafiq and Rana (2016) revealed a significant influence of emotional intelligence on organisational commitment. Emotional intelligence also shows a significant positive relationship with the three components of organisational commitment including affective, continuity and normative commitment. Emotional intelligence reflects a reasonable predictive power of teachers' organisational commitment. The study recommends that emotional intelligence should be included in teacher selection and recruitment criteria, and used as an intervention to increase teacher organisational commitment to Pakistani colleges. All of these research findings imply that emotional intelligence significantly affects organisational commitment

\section{Relationship between Spiritual Intelligence and Organisational Commitment}

The results of hypothesis 2 testing indicate that spiritual intelligence significantly affects organisational commitment $(t=2.38>1.96)$ with significance value $(.01<.05)$. Thus, hypothesis 2 is accepted. These findings are supported by research done by Kalantarkousheh et al. (2014) where the research results showed a correlation between spiritual intelligence and organisational commitment among staff. Staffs that have high spiritual intelligence will have good organisational commitment. Zohar and Marshall (2001) interpret spiritual intelligence as an intelligence to deal with the problem of meaning or value, namely the intelligence to put our behavior and life in the context of a broader meaning. Intelligence is used to assess whether one's actions or ways of life are more meaningful than others. In addition, Zohar and Marshall (2000) also stated that a person with high spiritual intelligence tends to be a dedicated leader, responsible for bringing higher vision and values and can inspire others as in line with the findings of Awais et al. (2015), EntesarFoumany and Danshdost (2014) and Kalantarkosheh, et al. (2014) which showed that spiritual intelligence is effective in maintaining and enhancing organisational commitment. All of these research findings imply that spiritual intelligence significantly affects organisational commitment.

\section{Relationship between Emotional Intelligence and Job Performance}

The result of hypothesis 3 testing shows that the emotional intelligence significantly affects job performance $(t=2.38>1.96)$ with significance value $(2.60<.009)$. Thus, hypothesis 3 is accepted. The research findings are supported by Utomo et al. (2014) and Akhtar et al. (2017). Their research results show that emotional intelligence has a positive impact on employee performance and the organisational support moderates the relationship between emotional intelligence and performance; thus, the relationship between emotional intelligence and work performance is stronger. In line with the study by Ma et al. (2013) which revealed that high performing employees not only actively solve problems but also enjoy working with fellow 
employees. When someone has a good emotional intelligence then the performance of the person in the environment of the organisation will also be good.

Vratskikh et al. (2016) suggested that emotional intelligence should be used to predict performance and job satisfaction, hence understanding theories of emotional intelligence can be promoted for managerial and human resource practices across public sector organisations. Meanwhile, Shih and Susanto (2010) found that emotional intelligence is the antecedent of conflict management within a company. In addition, it can also illustrate the immediate effects of conflict management on performance. The study also confirms that conflict management mediates the relationship between emotional intelligence and performance. The results of this research show that emotional intelligence in public organisations has an impact on performance similar to the emotional intelligence in private organisations. The stuidies conducted by Jasour and Avarsin (2016), Hasanuddin and Syahruddin (2017), Asghari and Shrivani (2015), Estanesti (2016) and Mahmood et al. (2015) revealed a significant relationship between emotional intelligence and job performance. All of these research findings imply that spiritual intelligence significantly affects organisational commitment.

\section{Relationship between Spiritual Intelligence and Job Performance}

The results of hypothesis 4 testing show that spiritual intelligence has no significant effect on job performance $(t=.005<1.96)$ with significance value $(.99>.05)$. It is obtained from the research results that spiritual intelligence has no effect on job performance. This condition explains that high or low level of spiritual intelligence possessed by a person does not have any impact on their job performance. It is caused by the existence of various factors beyond the spiritual intelligence that affect the level of one's job performance. Factors are meant here where one of them is related to the level of one's intellectuallity. When a person has only a high sense of dedication and responsibility (spiritual intelligence) toward a job but has no intellectual intelligenceit will not bring any change to job performance of someone. Intellectual intelligence refers to one's ability to absorb science and change where in a work environment a person is required to have a high intellectual intelligence. With a high level of intellectual intelligence, one will easily and quickly understand all forms of change and work model. By this, his ability to solve problems related to his work will get better. The results of this study are aligned or supported by research conducted by Oktariani, Setyanti, and Sumani (2016). Based on the results of t-test analysis, it is known that emotional intelligence and spiritual intelligence have no effect on employee job performance, while the personality affects employee performance. Emotional intelligence does not affect the job performance of employees because of the dominant respondents among the males while spiritual intelligence has no effect because the age of dominant respondents which is between 20-40 years old. However, in this study it shows that the variable of emotional intelligence and spiritual intelligence and personality simultaneously affect the performance of employees. The study by Yusnaena and Perdana (2015) indicated that spiritual intelligence has no effect on the performance of secretarial staff of the West Sumatra Provincial Representative.

\section{Relationship between Organisational Commitment and Job Performance}

The results of hypothesis testing 5 explain that organisational commitment positively affect job performance $(t=7.62>1.96)$ with significance value $* * *$ (very significant). Thus, hypothesis 5 
is accepted. This finding is supported by Khan et al. (2010) suggesting a positive relationship between organisational commitment and employee performance. In a comparative analysis of three dimensions of organisational commitment, normative commitment has a positive and significant impact on worker performance. Furthermore, this study explores employee job performance with four demographic variables, resulting in high achieving male employees dealing with their female counterparts. Similarly, research by Hafiz (2017) found that the three elements of organisational commitment are important factors in improving the performance of banking employees. The results show that the dimensions of organisational commitment independently and together affect the performance of employees in the bank.

Tolentino's (2013) research findings indicated that academics and administrative personnel differ significantly in terms of organisational commitment. Academics had higher affective and normative commitments. Among the three dimensions of organisational commitment, affective commitment was significantly related to the performance of academic staff. This finding is also in line with research conducted by Abarghuee, et al. (2014) that revealed significant relationship between organisational commitment and performance of sports teachers in high school. However, an analysis of the three components of organisational commitment shows that among the affective components of commitment, ongoing commitment and normative commitment, only affective commitment has a significant relationship with performance. Al Zefeiti and Mohamad (2017) also showed similar results of empirical research which indicate that all subscales of organisational commitment (affective, normative, and continuous) have a significant impact on performance. All of these research findings imply that organisational commitment significantly affects job performance.

\section{Discussion}

Based on the results obtained in the previous hypothesis testing, it is found that spiritual intelligence affects the performance but must go through organisational commitment. This condition indicates that a person who carries the meaning of spirituality in his work will feel his life and work, and will also have more meaning which will form a strong organisational commitment. The formation of organisational commitment will encourage and motivate individuals to make various efforts for organisational progress. This indicates a change in a person's performance when the business is doing a positive result.

In addition, individual performance is also influenced by the level of emotional intelligence possessed. A person with a high emotional intelligence will be able to manage his emotions and solve all problems faced. In this case, when one can solve problems in the world of work, then it does not rule out that someone will produce better performance.

Both aspects of this intelligence also play an important role in increasing one's organisational commitment. When an individual has both high spiritual and emotional intelligence, it will form a positive attitude, where the individual will have high integrity, responsibility and sincerity and will be able to solve various problems encountered in work environment. In this case the positive attitude will certainly result in a strong individual commitment to the organisation where he works.

\section{Standarized Direct Effect and Indirect Effect}


Table 4

Standardised Direct Effect

\begin{tabular}{lcccc}
\hline Constructs & Spiritual Intelligence & Emotional Intelligence & Organisational Commitment & Job Performance \\
\hline $\begin{array}{l}\text { Organisational } \\
\text { Commitment }\end{array}$ & .29 & .34 & .000 & .000 \\
Job Performance & .01 & .21 & .87 & .000 \\
\hline
\end{tabular}

Source: Data processed 2017

Table 5

Standardised Indirect Effect

\begin{tabular}{lcccc}
\hline Constructs & Spiritual Intelligence & Emotional Intelligence & Organisational Commitment & Job Performance \\
\hline Organisational & .000 & .000 & .000 & .000 \\
Commitment & .25 & .29 & .000 & .000 \\
Job Performance & & & & \\
\hline
\end{tabular}

Source: Data processed 2017

Based on the results of hypothesis testing, this research found that emotional intelligence significantly brings positive effects on the performance of nurses. Table 5 shows that indirect effect coefficient of spiritual intelligence toward job performance through organisational commitment is $.25>.001$. It means, spiritual intelligence has a positive effect toward temporary nurses' performance, but must be through organizational commitment. Indirect effect coefficient of emotional intelligence toward job performance through organisational commitment is $.29>.001$. It means, emotional intelligence has a positive effect on the performance of nurses, but must be through organisational commitment.

It is also found that both emotional and spiritual intelligence have a significant and positive effects on organisational commitment. And lastly, direct effect coefficient of organisational commitment has a significant positive effect and is the most dominant (.87) in influencing nurse's performance compared to other research variables.

\section{Implications}

Efforts to improve the performance of nurses are suggested to prioritise the improvement of organisational commitment, while efforts to increase organisational commitment is recommended to increase the emotional intelligence of nurses. For further research, it is advisable to develop the variables and research indicators to get more innovative results and should not be fixed on similar respondents. It is also expected that further research can apply and develop the current research model by synergizing the phenomena or facts that occur in the development of the current organisational environment.

\section{References}

Abarghuee, R. A., Broujerdi, Z. G., Naderian, M., \& Taherpour, F. (2014). An analysis of the relationship between organizational commitment and job performance among sport teachers at high schools in Ahvaz. Journal of Education and Practice, 5(2), 1-8.

Agustian, A. G. (2003). Emotional spiritual quotion (ESQ) power. Jakarta: Arga Motional Publishing.

Ahmadian, E., Hakimzadeh, A., \& Kordestani, S. (2013). Job stress and spiritual intelligence: a case study. World Applied Science Journal, 22(11), 1667-1676.

Akhtar, W., Ghufran, H., Husnain, M., \& Shahid, A. (2017). The effect of emotional intelligence on employee's job performance: The moderating role of perceived organisational support. Journal Acounting \& Marketing, 6(3), 1-8.

Alavi, S. Z., Mojtahedzadeh, H., Amin, F., \& Savoji, A. P. (2013). Relationship between emotional intelligence and organizational commitment in Iran's Ramin thermal power plant. Procedia-Social and Behavioral Sciences, 84, 815-819. 
Al Zefeiti, S. M.B., \& Mohamad, N. A. (2017). The Influence of organizational commitment on Omani public employees' work performance. International Review of Management and Marketing, 7(2), 151-160.

Asghari, M., \& Shirvani, A. (2015). The Relation between spiritual intelligence and hospital performance (Case Study: Therapeutic Personnel of Shahid Fayazbakhsh Hospital). International Journal of Academic Research in Business and Social Sciences, 5(3), 287-303.

Awais, M., Malik, M. S., \& Qaisar, A. (2015). A review: The job satisfaction act as mediator between spiritual intelligence and organizational commitment. International Review of Management and Marketing, 5(4), 203-210.

EntesarFoumany, G. H., \& Danshdost, M. (2014). The relationship of spiritual intelligence with mental health and organizational commitment among nurses in Mashhad hospitals. Journal of Educational and Management Studies, 3(4), 3639.

Estanesti, S. (2016). The study of impact spiritual intelligence on job performance of manager. International Academic Journal of Organisational Behavior and Human Resource Management, 3(5), 1-8.

Gibson, J. L., Ivancevich, J. M., \& Donelly, J. H. (2011). Organisation: Structure, process, behavior. Dallas: Business Publication, Inc.

Goleman, D. (2006). Emotional intelligence. Jakarta: PT Gramedia Pustaka Utama.

Hafiz, A. Z. (2017). Relationship between organizational commitment and employee's performance evidence from banking sector of Lahore. Arabian Journal Bussiness Management Review, 7(2), 304.

Hasanuddin, R., \& Sjahruddin, H. (2017). The structure of emotional intelligence, spiritual intelligence and its relationship with work enthusiasm and auditor performance. World Journal of Business and Management, 3(1), 67-85.

Jasour, M., \& Avarsin, S. M. (2016). The relationship between attributional style and spiritual intelligence and job performance of employees of Tabriz University of Medical Sciences. Res Dev, 5(2), 55-61.

Mohamadkhani, K., \& Lalardi, M. N. (2012). Emotional intelligence and organizational commitment between the hotel staff in Tehran, Iran. American Journal of Business and Management, 1(2), 54-59.

Kalantarkousheh, S. M., Sharghi, N., Soleimani, M., \& Ramezani, S. (2014). The role of spiritual intelligence on organizational commitment in employees of universities in Tehran Province, Iran. Procedia-Social and Behavioral Sciences, 140, 499-505.

Khan, M. R., Ziauddin, J. F., \& Ramay, M. I. (2010). The impacts of organizational commitment on employee job performance. European Journal of Social Sciences, 15(3), 292-298.

Ma, L., Xing, Y., Wang, Y., Chen, H. T. (2013). Research on the relationship among enterprise employee's job satisfaction, organizational commitment and job performance. In Applied Mechanics and Materials, 411, 2477-2480.

Mahmood, A., Arshad, M. A., Ahmed, A., Akhtar, S., \& Rafique, Z. (2015). Establishing linkages between intelligence, emotional and spiritual quotient on employees performance in government sector of Pakistan. Mediterranean Journal of Social Sciences, 6(6, S2), 553-560.

Mathis, R. L., \& Jackson, J. H. (2011). Human resource management: Essential perspectives. United States of America: Cengage Learning.

Meyer, J. P., \& Allen, N. J. (1984). Testing the "side-bet theory" of organizational commitment: Some methodological considerations. Journal of Applied Psychology, 69(3), 372-378.

Oktariani, W., Setyanti, S. W. L. H., \& Sumani, S. (2016). Pengaruh kecerdasan emosional dan kecerdasan spiritual serta kepribadian terhadap kinerja karyawan pada pt. BTN (PERSERO) TBK. Cabang Jember [Influence of emotional intelligence and ruhsal intelligence and personality to employee performance on pt. BTN (PERSERO) TBK. Jember Branch]. Jurnal Bisnis dan Manajemen, 10(2), 144-155.

Rani, A. A., Abidin, I., \& Hamid, M. R. (2013). The impact of spiritual intelligence on work performance: Case studies in government hospitals of east coast of Malaysia. The Macrotheme Review, 2(3), 46-59.

Rathi, N., \& Rastoghi, R. (2009). Assessing the relationship between emotional intelligence, occupational self-efficiency and organisational commitment. Journal of the Indian Academy of Applied Psychology, 35, 93-102.

Robbins, S. P. (1996). Organizational behavior: Concepts, controversies, and applications. University of Minnesota: Prentice Hall.

Rozeman, Y. (2007). Relationships between emotional intelligence and organizational commitment and job performance among administrators in Malaysian public university (Unpublished doctoral dissertation). University Putra Malaysia.

Shafiq, M., \& Rana, R. A. (2016). Relationship of emotional intelligence to organizational commitment of college teachers in Pakistan. Eurasian Journal of Educational Research, (62), 1-14.

Shih, H. A., \& Susanto, E. (2010). Conflict management styles, emotional intelligence, and job performance in public organizations. International Journal of Conflict Management, 21(2), 147-168. 
Tolentino, R. C. (2013). Organizational commitment and job performance of the academic and administrative personnel. International journal of Information technology and Business Management, 15(1), 51-59.

Utomo, H. J. N., Nimran, U., Hamid, D., \& Utami, H. N. (2014). The effect of spiritual and emotional intelligence on the job satisfaction and organizational commitment: Study on salespersons of motorcycles in special region of Yogyakarta. International Journal of Management and Administrative Sciences, 4(1), 74-83.

Vratskikh, I., Al-Lozi, M., \& Maqableh, M. (2016). The impact of emotional intelligence on job performance via the mediating role of job satisfaction. International Journal of Business and Management, 11(2), 69-91.

Yusnaena, Y., \& Perdana, A. (2015). Emotional intelligence effect and side of gender spritual intelligence against performance of employees in the west Sumatra staffing parliament. DeReMa (Development Research of Management), Jurnal Manajemen, 10(1), 138-161.

Zohar, D., Marshall, I. (2001). SQ: Connecting with our spiritual intelligence. USA: Bloomsbury Publishing. 